УДК 332.834.7:355.1(477) «2014/2021»

БУРАКОВ Ю.В.

https://orcid.org/0000-0001-7180-4469

ТОМЧУК О.А.

https:/ orcid.org/0000-0002-9476-4348

https://doi.org/10.33577/2313-5603.36.2021.27-44

\title{
ВІДРОДЖЕННЯ КАПЕЛАНСТВА В СУЧАСНОМУ УКРАЇНСЬКОМУ ВІЙСЬКУ
}

У статті аналізується процес відродження капеланства у сучасному українському війську. Пропонується історична періодизація цього явища. Наголошується, що Інститут військових капеланів для 3С України виник із волонтерської душпастирської служби. Сотні священників-волонтерів після нападу Російської Федерації на Україну, анексії Криму та окупації районів Донецької та Луганської областей, разом із добробатами вирушили на Схід України з метою захисту й відсічі російському агресору. Розглядається становлення нормативно-правової бази капеланської служби. Констатується, що відродження душпастирської служби $\epsilon$ серйозною духовною основою зміцнення морально-психологічного стану військ, згуртування військових колективів і успішного виконання бойових завдань.

Ключові слова: капелан, душпастирська служба, волонтер-священнослужитель, волонтерський рух допомоги Збройним Силам України.

Актуальність проблеми. Явище капеланства в Україні має давні історичні традиції: душпастирська опіка була у козацькому війську, легіоні Українських Січових Стрільців, Українській Галицькій Армії, Армії УНР, Українській Повстанській Армії. Під час Першої світової війни в лавах Австро-Угорської армії нараховувалось близько 100 капеланів українського походження (так звані фельдкурати або польові духівники, військові священники). В армії УПА були священники від греко-католиків, православних, протестантів.

У незалежній Україні відбувається процес відродження капеланства у Збройних Силах. Душпастирство у середовищі військових має важливе значення, оскільки служить одним iз основних

Бураков Юрій Васильович, кандидат історичних наук, доцент, провідний науковий співробітник Наукового центру Сухопугних військ Національної академії сухопутних військ імені гетьмана Петра Сагайдачного, м. Львів.

Томчук Олександр Анатолійович, доктор філософії, начальник відділу Наукового центру Сухопутних військ Національної академії сухопутних військ імені гетьмана Петра Сагайдачного, м. Львів.

(С) Бураков Ю. В., Томчук О. А., 2021. 
засобів морально-психологічного забезпечення військ. Вивчення процесу відродження капеланської служби у ЗС України, становлення іiі законодавчої бази, сучасної діяльності душпастирів у ході проведення Антитерористичної операції (АТО) та операції Об'єднаних сил (ООС) є однією із маловивчених й разом з тим важливою проблемою сучасної воєнної історії.

Метою даної наукової розвідки є дослідити історію відродження капеланської служби у ЗС України, запропонувати й обгрунтувати періодизацію цього процесу, навести приклади душпастирського служіння капеланів-волонтерів у зоні АТО, висвітити правове формування інституту капеланства на сучасному етапі.

Iсторіографія проблеми знаходиться у стадії формування. Історія капеланства в сучасних 3С України не повною мірою вивчається в наукових інституціях, оскільки ця проблема нова й повстала вона із захистом нашої Вітчизни від збройної агресії Російської Федерації, розпочатої вторгненням навесні 2014 р. Першопроходцями в ній виступають журналісти, блогери, соціологи. Вони формують й історичні джерела 3 проблеми, проводячи інтерв'ю 3 військовими душпастирями, священнослужителями різних релігійних концесій, учасниками АТО. Цінними є спогади священнослужителів-волонтерів.

Виклад основного матеріалу. Безпосередню співпрацю церков i релігійних організацій із ЗС України можна поділити на два етапи. Перший - 3 грудня 1991 р., з часу проголошення незалежності України й до початку військової агресії Російської Федерації 22 лютого 2014 р. Другий - від початку російськоукраїнської війни й до сьогодні. Перший період - це період становлення й налагодження співпраці церков i релігійних організацій із військовими частинами.

12 травня 1994 р. у Львові на науково-практичному симпозіумі «Духовно-гуманітарні проблеми розбудови Збройних Сил України» була започаткована (як консультативний орган) «Міжцерковна рада $з$ питань душпастирської роботи у збройних формуваннях України». Згодом питання задоволення релігійних прав і свобод в армії було актуалізовано на регулярних конференціях «Армія і духовність: свобода совісті та віровизнання», в якій брали участь чимало представників силових структур, науковців та духовенства. 
У 1999 р. чергова конференція на тему: «Армія і духовність: свобода совісті та віровизнання» вже звернулася до Президента України, як Верховного Головнокомандувача з низкою пропозицій щодо теоретичного, юридичного та практичного започаткування діяльності душпастирської опіки у війську. Однак, належної реакції від офіційної влади тоді не дочекалися» (Томчук, 2017: 160).

У 2000 р. у Львові на черговій конференції «Армія і духовність: свобода совісті та віровизнання» було прийнято рішення про утворення «Всеукраїнського міжконфесійного релігійного християнського військового братства». «Нова організація поставила собі за мету домагатися від влади створення інституту військового духовенства і налагодження співпраці у цій сфері між різними Церквами» (Бураков, 2020: 190-191).

У 2000 - 2004 pр. організовано перші міжнародні капеланські навчання за участю запрошених військових душпастирів зі США, слухачами яких стали 150 священиків та семінаристів різних конфесій з України. Священиків почали частіше залучати до війська насамперед під час проведення різних урочистостей. Велике значення мало відкриття за участю духовенства та широкої громадськості каплиць та храмів у військових частинах (Друздєв, 2017: 433-435). Очевидно, що цього було замало, а головно, їхня праця потребувала правового визнання.

Особливу активність щодо творення капеланських структур проявляла Українська греко-католицька церква (УГКЦ). 2005 р. у Львові була освячена церква Архистратига Михаїла, яка знаходиться на території Національної академії сухопутних військ імені гетьмана Петра Сагайдачного (далі - НАСВ). При цьому храмі розпочав формуватися львівський осередок капеланів, який очолив отець Степан Сус (нині - єпископ УГКЦ). За кілька років осередок розрісся до Центру військового капеланства при Львівській архиєпархії УГКЦ.

Для кращого розуміння армійського життя отець Степан Сус почав проходити всі навчальні програми разом із солдатами та курсантами. Найбільш пам'ятним для нього став марш-кидок на 72 км 3 десантниками. Завдяки спільному проходженню всіх труднощів солдатського життя його авторитет зростав 3 кожним 
днем. До храму все частіше почали приходити як звичайні курсанти, так і керівництво. Зокрема не останню роль в успіху львівського капеланства відіграв керівник Львівського гарнізону, начальник Національної академії сухопутних військ імені гетьмана Петра Сагайдачного - генерал-лейтенант П.П. Ткачук, який активно сприяв відновленню львівських храмів, зокрема гарнізонному храму святих апостолів Петра і Павла, неподалік від відомої Площі Ринок.

Ідея відкрити у Львові Гарнізонний храм - святиню для військових - зародилась в Академії сухопутних військ ще у 2008 р. Позаяк «вільних» церков у Львові не було, вибір упав на костел єзуїтів, який вже виконував функцію «військового» храму із середини XIX століття до кінця $30-\mathrm{x}$ років XX ст. Вагомою перепоною на шляху втілення цієї ідеї стало книгосховище Львівської національної наукової бібліотеки ім. Василя Стефаника НАН України, яке розташовувалось у храмі. Туди після завершення Другої світової війни було завезено більше мільйона конфіскованих радянською владою книг. Однак спільними зусиллями Президії НАН України, Церкви, міської ради та командування Національної академії сухопутних військ «протягом жовтня-листопада 2011 р. храм вдалося звільнити від книг шляхом перевезення їх до іншого сховища - приміщення, наданого НАСВ» (Томчук, 2018: 171).

6 грудня 2011 р. висвятили Гарнізонний храм святих апостолів Петра і Павла. Він є єдиним храмом 3 таким статусом в Україні. У ньому, крім військових капеланів, проводять служби ще капелани дітей-сиріт. Цей храм став одним із головних осередків збору волонтерської допомоги Євромайдану у м. Львові. Священнослужителі України усіх конфесій були активними учасниками Революції гідності (листопад 2013 р. - лютий 2014 р.)

Навесні 2014 р. розпочався другий етап відродження душпастирської служби у ЗС України. Внаслідок агресії Російської Федерації проти України священнослужителі опинилися поруч із військовими в районах реальних бойових дій та під час виконання ними бойових завдань, відтак актуалізувалося питання щодо справедливого соціального захисту їх під час своєї діяльності. Нарешті 2 липня 2014 р. Кабінет Міністрів України видав Розпорядження 
№ 677 р. «Про службу військового духовенства (капеланську службу) у Збройних Силах, Національній гвардії, Державній спеціальній службі транспорту та Державній прикордонній службі» (Кабінет Міністрів України - Розпорядження від 2 липня 2014 р. № 677-p.).

Вибух громадсько-політичної активності населення навесні 2014 р., зокрема масової участі громадян у волонтерській допомозі ЗС України, вплинув і на церковно-релігійні структури, які також започаткували волонтерські ініціативи, спрямовані на допомогу учасникам АТО, їхнім сім'ям, переселенцям. Справжніми духовними подвижниками в час російської агресії стали капелани українських церков.

Військовий капелан М. Бучак з Волині згадує: «Ще тоді таке поняття, як «військовий капелан», не звучало, були просто священники-волонтери. Але вже тоді я зрозумів, що головне завдання військового священника - виконати волю Божу, не противитись ій. А він Сам усе зробить. Він Сам підкаже. Ти всього-на-всього виконуєш роль провідника, магнітофона, на який записують інформацію. Ти виконуєш роль громовідводу, пропускаючи крізь себе біль душі солдата. I все. Не треба перебільшувати своєї ролі. Коли починаєш вважати себе якимось великим цабе, ти втрачаєш все. Так почалося моє служіння вже капеланське. Далі були знову волонтерські поӥздки. Форми, берці, рації, авто... Боже, скільки всього було, який неймовірно жертовний український народ! Низький уклін вам, Люди! Війна об'єднала всіх. Коли мене запитують: «Кого всіх?»-я кажу: «Тих, у кого українське серце». Не українська мова, не обов'язково прапор через груди чи ще щось, а українське серце. Якщо серце синьо-жовте - значить, це українець, і він зробить усе, що необхідно» (Капелани, 2019: 232).

В українському війську 3 початком російсько-української війни перебувають капелани-добровольці найрізноманітніших конфесій. Вони займалися волонтерською діяльністю, поєднуючи iii 3 душпастирським служінням. Так, капелан-волонтер від Християнської євангельської церкви Л. Когут розповідав: «У мене близько 30 поїздок у зону бойових дій. Буває, приїжджаєш в частину, питаєш: «Хлопці, є капелан?». Кажуть: «є». «А якої 
конфесії?». «Не знаємо». Ми працюємо з усіма, навіть із мусульманами. Була така ситуація, що батько, який щойно повернувся 3 війни, передавав через нас сину освячені мусульманські чотки. Потім я знайшов для того хлопця капелана-мусульманина. I колега їздив до нього, аби підтримати. А як інакше?» (Вовкодав).

Військовий священнослужитель може взяти до рук зброю лише 3 метою допомогти воїну, який потрапив у стресову ситуацію, аби він не наробив шкоди ні собі, ні іншим воїнам. «У нас був випадок, - розповідає владика Іоан (Яременко), - коли необстріляний воїн у стресовому стані після першого бою нікого до себе не підпускав і погрожував, що усіх розстріляє. До нього вдалося підійти лише капелану. Він заспокоїв солдата і забрав зброю». Крім того, один із очільників українського капеланства зауважив, що зброя сама по собі не $є$ злом, не $є$ скверною. Тим більше коли вона використовується для захисту Батьківщини. «Тому в нас $є$ чин освячення зброї, яка захищає Батьківщину, - пояснює владика Іоан. - Цей чин ще 3 древності прописаний в наших богослужбових книгах. Тож зараз священник може взяти в руки зброю з метою душпастирською, але не 3 метою виконання бойових задач» (Вовкодав). Щодо захисту особи капелана міжнародною практикою передбачено помічника, який обирається із військовослужбовців і має штатну зброю. Капелани деяких країн мають право озброюватися, але в Україні такої практики немає.

Церква також максимально долучилася i до волонтерської допомоги як військовослужбовцям, так і населенню окупованої території. Наприклад, разом із групою волонтерів 3 м. Золочева (Львівська обл.) на передову АТО неодноразово відвозили харчі, медикаменти та інші необхідні речі військові капелани отці Михайло (Сукмановський), Юрій (Галабуда), Михайло (Костик) та Ігор (Салабай) (Військові капелани про поӥзду на передову).

Отець Юрій (Галабуда) - священник золочівського храму блаженного Миколая Чарнецького на Львівщині. Уродженець села Вороняки на Золочівщині. Навчався у Львівській духовній семінарії, і вже під час навчання брав участь у різних організаціях. 32004 р. отець Юрій працює у військовому капеланстві. За цей час був у різних структурах: Державна прикордонна служба України, Збройні Сили, Внутрішні війська (теперішня Нацгвардія). 
3 початком АТО регулярно проводив службу у зоні бойових дій. Він говорить: «Теперішні події - велика нагода щось кардинально змінити. Воювати мусимо. Маємо молитися і допомагати. Маємо трудитися для нашого війська, маємо бути біля нашого війська, маємо завжди їх підтримувати» (Судін).

Війна безпосередньо торкнулася й українських дітей - в зоні бойових дій з'явилося багато сиріт, тих, у кого загинули батьки. Військові капелани і тут не залишилися осторонь: вони допомагають таким дітям влаштовуватися у дитячі будинки, школиінтернати, піклуються про їх усиновлення, створюють реабілітаційні центри, а деякі навіть беруть сиріт до себе на виховання.

Пастор капелан Геннадій (Мохненко), батько трьох рідних і 32 прийомних дітей, створив в Маріуполі найбільший на всьому пострадянському просторі реабілітаційний центр для дітейбезпритульників під назвою «Республіка Пілігрим». Його дитбудинок пережив дві евакуації (Капелан и отеи 35 детей...).

Ефективна робота військових капеланів у зонах бойових дій, де вони фактично замінюють психологів і укріплюють боєздатність особового складу, підтверджує необхідність існування такого інституту в ЗСУ.

Основним призначенням військового священника (капелана) $\epsilon$ релігійна опіка особового складу ЗС України та членів їх сімей 3 метою заохочення, поглиблення релігійного життя, сприяння укріпленню позитивних рис характеру та моральних цінностей.

Напрямами діяльності капелана є:

задоволення релігійних потреб військовослужбовців;

релігійно-освітня робота;

індивідуальна душпастирська опіка особового складу;

соціально-доброчинна діяльність;

душпастирська опіка сімей військовослужбовців та ветеранів.

Основними завданнями капелана є:

організація та проведення молитов, богослужінь, благословінь, урочистих і поминальних заходів та інших релігійних обрядів і культів, пов'язаних із задоволенням релігійних потреб військовослужбовців, а також визначними державними та релігійними датами;

ознайомлення військовослужбовців 3 основами релігійного вчення; 
виховання у військовослужбовців високого патріотичного почуття та бойового духу на основі морального і духовного потенціалу релігійної та культурної спадщини українського народу;

виховання у військовослужбовців толерантного ставлення до людей з інакшими світоглядними та релігійними переконаннями;

ознайомлення особового складу 3 історією національного, культурного та релігійного становлення української державності;

допомога військовослужбовцям у розвитку їх особистих та колективних моральних якостей: братерства, мужності, хоробрості, відповідальності, поміркованості, жертовності, дисциплінованості, розсудливості тощо;

налагодження партнерських відносин з представниками релігійних організацій різних конфесій, які діють у місцях дислокації військових частин;

забезпечення військовослужбовців релігійною атрибутикою, духовною літературою та іншими речами, потрібними для задоволення їхніх релігійних потреб;

участь у реабілітації військовослужбовців, які потребують психологічної допомоги

душпастирське піклування про членів сімей військовослужбовців;

надання всебічної душпастирської опіки та турботи всім військовослужбовцям і членам їх сімей;

формування серед військовослужбовців братерських взаємин на засадах принципів солідарності, гуманності та почуття святості військового обов'язку .

3 початком російської агресії підготовка капеланів в Україні почала здійснюватися на державному рівні. Так, в лютому 2017 р. в НАСВ були організовані пілотні «Курси навчання капеланів» (У Національній академій сухопутних військ завершився перший в Украӥні Курс військових капеланів за участі іноземних інструкторів). Впродовж двох тижнів представники різних релігійних конфесій, що входять до Ради у справах душпастирської опіки при Міністерстві оборони України, обговорювали проблематику, яка виникає під час роботи капеланів у військах, та вивчали іноземний досвід служби священників у Збройних Силах. Цей досвід українському духовенству передавали представники 
Королівської служби капеланів Канади. У Курсах підготовки військових капеланів взяли участь 24 священнослужителі, серед яких є християни - представники православних конфесій, грекота римо-католики, євангельські християни - баптисти, п’ятидесятники, євангелісти, а також капелани-імами.

Подібні заходи були у Київській Богословській семінарії, в парафіях УГКЦ. Відбувався активний обмін досвідом пастирської роботи в зоні АТО. Курси капеланів регулярно відвідує зарубіжна місія капеланів, іноземні інструктори залучені до підготовки військових священників.

Душпастирська служба з часу виникнення теперішньої війни пройшла етапи від стихійного волонтерського капеланства до організації штатної структури у ЗС України. Так, на сьогоднішній день інститут капеланів юридично оформлений, штатна структура капеланської служби затверджена і військові душпастирі приступають на законних підставах до роботи у військах ЗС України. Згідно з Постановою Кабінету Міністрів 315 травня 2017 р. у всіх бойових частинах та підрозділах 3С України затверджуються посади військових капеланів.

Списки кандидатів були попередньо погоджені душпастирською Радою при Міністерстві оборони України. Після співбесіди 3 командирами військових частин капелани отримують призначення. Встановлення капеланства у ЗС України здійснюється у два етапи: на першому етапі, до кінця червня 2017 р., військові капелани були призначені до бойових частин та підрозділів, а на другому, до кінця 2017 р., - в усі підрозділи Збройних Сил України.

Передбачено, що у бойових бригадах працюватиме від 2 до 4 військових священників. В той же час МО України не відмовляється від волонтерської місії, яку у військах здійснюють українські конфесії, тому нештатні капелани-волонтери зможуть постійно знаходитись з бійцями на передовій (Військові капелани запрацююють у всіх бойових частинах вже з 15 травня 2017р.).

«С священники, які вже закінчили військові кафедри, - повідомляє голова Синодального управління військового духовенства, - зокрема, це військовий інститут Національного університету імені Тараса Шевченка та кафедра військової підготовки 
Національного університету біоресурсів та природокористування» (Вовкодав).

Встановлення для капеланів штатних посад у військових підрозділах стало викликом для конфесій, що діють на території України. «Планується, що Законом України буде передбачено не більше 500 воїнів на одного капелана, - розповідає владика Іоан. Якщо врахувати чисельність нашої армії зараз, то жодна конфесія не готова надати таку кількість капеланів. Отже, нам потрібен певний час, аби виховати плеяду військових священників, які матимуть відповідну освіту» (Вовкодав). Процес нарощування капеланського потенціалу в Україні продовжується. Адже війна триває, а атеїстів на війні, за словами учасників АТО - ООС, практично не буває.

3 початком російської агресії, вже навесні 2014 р. сотні священників добровільно вирушили на передову. Наприклад, ієромонах Макарій із чоловічого православного монастиря у м. Жидачеві (Львівська обл.) пішов капеланом на службу у зону АТО ще від початку проведення бойових дій (Монах з Волині на передовій з початку АТО).

Капеланами-волонтерами у зону АТО пішли священнослужителі УГКЦ (Української греко-католицької церкви) отці Іван (Гопко), Юрій (Лисишин), Любомир (Яворський), Іван (Гуня) та багато інших. За перші два роки бойових дій на Сході України було здійснено 395 ротацій (кожна по 35 - 45 діб) священників УГКЦ у зоні АТО (О. Любомир Яворський). В цілому, з весни 2014 р. (початку російської агресії) УГКЦ (станом на 29 грудня 2016 р.) провела 474 ротації священників в зоні бойових дій терміном 30 - 45 днів. Тільки за перші два місяці 2017 р. у зоні АТО працювало 152 греко-католицьких військових капелани (Капелани УГКЦ в зоні АТО).

У бойовій обстановці на душпастиря покладається вирішення таких завдань: моральна та духовна підтримка воюючих, допомога пораненим, їхня евакуація, проведення служб та похорону, робота із військовополоненими.

Згідно з існуючими правилами капелани працюють у підрозділах, що діють на передньому краї, якнайближче до лінії вогню. Додатковими функціями діяльності капелана у війську є залучення його до членства в комісіях із заохочення, розслідування 
злочинів, улагодження конфліктів та створення доброзичливого мікроклімату у військових частинах.

Багато волонтерів-священників за сумлінну душпастирську працю відзначено високими нагородами. Наприклад, капелан УГКЦ отець Андрій Зелінський, автор книги «Соняхи. Духовність на час війни», який постійно здійснював служіння у зоні АТО, один із перших нагороджений орденом «Народний Герой України» (Капелана Андрія Зелінського нагороджено орденом «Народний Герой Украӥни»).

Під час бойових дій, в екстремальних умовах для бійця нерідко не має значення приналежність пастиря до певної конфесії, бо всі ці відмінності перекриваються прагненням людини на межі життя і смерті почути слово Боже, прочитати молитву, сповідатися, покаятися, причаститися.

Наприклад, в зоні бойових дій виконує свої пастирські обов'язки капелан протестантської церкви «Філадельфія» В'ячеслав (Бевз), який пройшов підготовку на курсах в Центральному Будинку офіцерів 3С України, здійснював душпастирську опіку українських бійців у частинах й підрозділах у боях під Волновахою, Маріуполем та інших районах бойових дій. Військовослужбовці довіряють йому, прислухаються до його порад хоча б тому, що він разом з ними під вогнем противника долає усі тяготи окопного життя і краще за інших бачить і знає потреби солдатів на війні (Капелан Вячеслав Бевз). Для воїнів у цьому випадку стає неважливою приналежність духовного отця до конкретної релігійної організації, парафії або конфесії.

Волонтери-священнослужителі під час поїздок на передову лінію фронту виступали і джерелом інформації 3 високим рейтингом довіри, особливо якщо йшлося про «гарячі новини» iз зони АТО. Новини волонтерів-капеланів про ситуацію на фронті ставали джерелом інформації і масово поширювалися в друкованих та електронних засобах масової інформації. I мова не лише про бої, а особливо - про втрати, смерті, поранення наших бійців, проведення рятувальних робіт серед цивільного населення у зоні АТО - ООС.

До функцій волонтерів-священників у бойових дій на Сході України входили, перш за все, проведення сповіді, причастя, 
відспівування загиблих, а також освячення техніки, індивідуальні бесіди 3 військовослужбовцями, проведення занять із християнської етики.

Надзвичайно важливою $\epsilon$ роль волонтерів-священників у знятті стресового синдрому та укріпленні морально-психологічного стану військовослужбовців. Ця плідна напружена робота має позитивні результати. Наприклад, командування 81-ї ОАБ проінформувало ЗМІ, що за час опіки з'єднання капеланами УГКЦ у бригаді не сталося жодного випадку самогубства (Блаженніший Святослав...).

Волонтери-священнослужителі ведуть історію своєї діяльності із часів Євромайдану, вони приймали активну участь у створенні добровольчих батальйонів, які захистили незалежність Держави. Капелан УПЦ (КП) Валентин (Сєровецький) один 3 перших організував проведення ранкових молебнів на сцені Майдану, а після його перемоги благословляв перші добровольчі батальйони з числа активістів Свромайдану перед відправкою їх на Схід України. Отець Валентин - військовий священник 92-ї бригади ЗСУ, а згодом капелан батальйону «Айдар», пройшов війну i важкий полон в «ЛНР», але загинув в автомобільній катастрофі (Під Києвом загинув капелан, який побував у полоні «ЛНР»).

Важливим моментом в організації пастирської опіки особового складу ЗС України є створення низки громадських організацій, таких як «Міжконфесійний батальйон військових капеланів». Перші поїздки капеланів-волонтерів із цієї організації у зону АТО почалися ще у квітні 2014 р. й тривають донині. За період існування батальйону було зроблено більше сотні виїздів волонтерів-священників «Міжконфесійного батальйону військових капеланів». На час завершення АТО та переходу іiі до стадії OОС, в складі батальйону, за попередніми підрахунками, служили більше 100 духовників, підготовлених для роботи на фронті.

Капелани «Міжконфесійного батальйону військових капеланів» у період 3 осені 2014 р. і до весни 2015 р. вели пастирське служіння в Донецькому аеропорту не тільки як священники, але і в якості психологів та парамедиків. У складі «Міжконфесійного батальйону військових капеланів» працювали капелани-інструктори 3 тактичної медицині і медичної евакуації, які здатні 
навчати військовослужбовців наданню першої допомоги при пораненнях. 32016 р. на базі батальйону був створений підрозділ військових психологів для роботи як в зоні АТО, так і в навчальних центрах (Батальйон військових капеланів).

Ще одним напрямом стала робота волонтерів-священників із реабілітації військових, що повернулися із зони бойових дій. «Всеукраїнське міжконфесійне релігійне християнсько-військове братство» реалізує Програму діяльності на 2017 - 2021 рр., яка включає в себе акцію «Солдат повертається додому» (Програма «Солдат повертається до дому» в діï).

Триває створення законодавчої бази капеланської служби. Ухвалити закон щодо військового капеланства парламент України досі не спромігся - попри те, що законопроєктів за цей час було розроблено аж три.

Перший за № 10244-1 Верховна Рада України попереднього VIII скликання в червні 2019 р. навіть ухвалила у першому читанні. Проте після позачергових парламентських виборів законотворчий процес щодо цієї теми в Раді нового скликання розпочався наново.

У вересні 2020 р. був зареєстрований у Верховній Раді законопроєкт № 4148 «Про військове капеланство у Збройних Силах України», але який згодом відкликали.

Ще один проєкт «Закону про Службу військового капеланства» № 4626 було подано до Верховної Ради вже в січні 2021 р. Документ розглянув парламентський комітет 3 питань національної безпеки, оборони та розвідки. У травні 2021 р. Верховна Рада прийняла за основу законопроєкт № 4626 «Про Службу військового капеланства», який утворює Службу військового капеланства як самостійний структурний підрозділ у складі військових формувань. Зазначається, що капелани є військовослужбовцями та мають відповідні соціальні гарантії.

Блаженніший Святослав - глава УГКЦ, згадуючи важкий шлях українського військового душпастирства, який розпочався після здобуття Україною незалежності, говорив: «Коли грекокатолики вперше постукали до брам військових частин, їм було дуже непросто. Адже командування ще перебувало під впливом радянських стереотипів, не розуміючи ролі й місця священника в армії. Замполіти тривалий час вважали, що можуть замінити 
будь-кого - від тата і мами до духовника. Перелам стався відносно недавно. Капелани пішли з Свромайдану із добровольцями у степи Донбасу - на передову і в дії показали, хто є такі. Наразі статус військового капелана поволі набуває звичних для багатьох розвинених країн правових абрисів, закріплюючи їх як штатну інституцію Збройних Сил» (Карпюк).

Висновки. Таким чином, до початку російсько-української війни (2014р.) становлення процесу військового капеланства мало безсистемний та спорадичний характер. Важливу роль тут відіграло відкриття храмів, каплиць на території дислокації військових частин, організація курсів підготовки священнослужителів для 3С України, утворення «Всеукраїнського міжконфесійного релігійного християнського військового братства» (2002 р.).

Визначаючим чинником у відродженні інституту капеланства в Україні була участь священників-добровольців у відсічі російській агресії на Сході України. Сотні священників-волонтерів разом із добробатами вирушили на фронт з метою захистити Вітчизну. Значний був їхній внесок у розгортанні волонтерської допомоги для 3С України. Вони були серед організаторів збору гуманітарної допомоги.

Інститут військових капеланів для ЗС України відродився iз волонтерської душпастирської служби. Душпастирська служба $\epsilon$ серйозною духовною основою зміцнення морально-психологічного стану військ, згуртування військових колективів і успішного виконання бойових завдань. Це підтверджує система підготовки і практика душпастирської опіки у зоні АТО - ООС.

Слід констатувати, що правове оформлення капеланства дещо затягнулося. На часі є прийняття незабаром Закону «Про Службу військового капеланства», який законодавчо завершить процес відродження військового капеланства у ЗС України й надасть новий поштовх розвитку душпастирського служіння у Збройних Силах України.

\section{Використані посилання}

Бураков Ю.В. (2020) Відродження капеланства у сучасному українському війську. Украӥнське військо: сучасність та історична ретроспектива: збірник матеріалів I Міжнародної науково-практичної конференції. 27 лист. 2020 р. Київ. НУОУ, С. 190-194. 
Військові капелани запрацюють у всіх бойових частинах вже з 15 травня. URL: https://www.kapelanstvo.ugcc.ua/vijskovi-kapelany-zapratsyuyut-u-vsih-bojovyhchastynah-vzhe-z-15-travnya/. (Дата звернення: 02.02.21)

Військові капелани про поїдку на передову. URL: https://www.youtube.com/watch?v=FND3AwqoVTk. (Дата звернення: 02.02.21)

Вовкодав Ю. Духовенство в камуфляжі: як капелани служать у зоні АТО. URL: https://www.suvd.com.ua/uk/articles/duhovenstvo-v-kamufljazhi/show. (Дата звернення: 02.02.21.)

Друздєв О. (2017) Душпастирська опіка. «Між війною $i$ соборністю. Соціокультурна інтеграиія та адаптаџія переселенців з Донбасу та Криму. Західноукраїнський вектор». Національна академія наук України, Інститут українознавства ім. І. Крип'якевича. Львів. С. $433-440$.

«Про службу військового духовенства (капеланську службу) у Збройних Силах, Національній гвардії, Державній спеиіальній служббі транспорту та Державній прикордонній службі». Розпорядження Кабінету Міністрів України від 2 липня 2014 p. № 677-p.

Капелан Вячеслав Бевз: «Солдаты думали, что мы их забросаем цитатами из Библии, а мы стали просто с ними жить». URL: http://www. theinsider.ua/politics/5497bf2b1a684/. (Дата звернення: 09.09.21).

Капелан и отеи 35 детей: хочу рассказывать правнукам, как империя сломала зубы под Мариуполем. URL: https://www.obozrevatel.com/interview/-90348-gennadijmohnenko-kapellan-mariupol.htm]. (Дата звернення 09.09.21).

Капелана Андрія Зелінського нагороджено орденом «Народний Герой України». URL: http://glavnoe.ua/news/n221286]. (Дата звернення: 09.09.21).

Капелани УГКЦ в зоні АТО. URL: https://www.kapelanstvo.ugcc.ua/category/novyny/kapelany-ugkts-v-zoni-ato/. (Дата звернення: 09.09.21).

Ковтунович Т., Привалко Т. (2019) Капелани. На службі Богу $і$ Украӥні. Український інститут національної пам'яті. Київ. ФОП Гончарук А.Б., 424 с.

Карпюк Г. (2016) Капелани - духовні батьки украӥнських героїв. URL:http://news.ugcc.ua/articles/kapelani_duhovn\%D1\%96_batki_ukrainskih_ger oiv_77964.html (Дата звернення: 09.09.21).

Монах з Волині - на передовій з початку ATO. URL: https://www.volynnews.com/news/vidsichagresoruukrayinayedina/monakh-z-volyni-na- peredoviy-z-pochatkuato/ (Дата звернення: 09.09.21).

Отеиь Любомир Яворський: За час війни на Сході вже відбулося 395 ротаиій священиків УГКЦу зону АТО. URL: http://catholicnews.org.ua/o-lyubomir-yavorskiyza-chas-viyni-na-shodi-vzhe-vidbulosya-395-rotaciy-svyashchenikiv-ugkc-u-zoni]. (Дата звернення: 09.09.21).

Під Києвом загинув капелан, який побував у полоні «ЛНР». URL: https://styler.rbc.ua/ ukr/zhizn/kievom-pogib-kapellan-pobyvavshiy-plenulnr-1475513871.html. (Дата звернення: 09.09.21).

Програма «Солдат повертається до дому» в діï. URL: http://viraichest. com.ua/index.php? option=com_content \&view =article\&id=9:2011-05-0916-47-16\&catid=1: bratstvo \&Itemid=6. (Дата звернення 09.09.21).

Судін К. Вони стоять заради нас... URL: http://old.dyvensvit.org/-articles/ 104871.htm (Дата звернення: 09.09.21). 
Томчук О.А. (2017) Душпастирська служба у зоні АТО серед військовослужбовців Збройних Сил України та волонтерів. Збірник матеріалів II Bceукраїнської науково-практичної конференції «Українське військо: сучасність та історична ретроспектива». Київ: Національний університет оборони України імені Івана Черняховського. С. 160.

Томчук О.А. (2018) Душпастирська опіка у волонтерському русі: окремі приклади. Про гідність. Волонтерський рух в Україні 2013-2017 років. Національна академія наук України, Інституг українознавства імені Івана Крип'якевича. Львів, с. 280-284.

У Національній академій сухопутних військ завершився перший в Украйні курс військових капеланів за участі іноземних інструкторів. URL: http:// www. asv.gov.ua /?q=news/2017/02/10/u-nacionalniy-akademiy-suhoputnyh-viysk-pershyy-v-ukrayini-kurs. (Дата звернення: 09.09.21).

\section{References}

His Beatitude Sviatoslav met with military chaplains in Kramatorsk. URL: https://www.youtube.com/watch?v=K7Um9sNtSfk (Accessed 02.02.21.)

Burakov Yu. (2020) Revival of chaplaincy in the modern Ukrainian army. Ukrainian Army: modernity and historical retrospective: collection of materials I International scientific-practical conference. 27 November 2020. Kyiv. National Defense University of Ukraine, p. 190-194.

Military chaplains will work in all combat units since May 15. URL: http://kapelanstvo.org.ua/vijskovi-kapelany-zapratsyuyut-u-vsih-bojovyh-chastynahvzhe-z-15-travnya/]. (Accessed 02.02.21.)

Military chaplains about a trip to the advanced anti-terrorist operation. URL: http://zolochiv.net/vijskovi-kapelany-pro-pojizdku-na-peredovu-ato-video/. (Accessed 02.02.21.)

Vovkodav Yu. Clergy in camouflage: how chaplains serve in the anti-terrorist operation zone. URL: https://opinionua.com/2018/02/28/duxovenstvo-v-kamuflyazhiyak-kapelani-sluzhat-u-zoniato/. (Accessed 02.02.21.)

Druzdiev O. (2017) Pastoral care. "Between war and catholicity. Socio-cultural integration and adaptation of migrants from Donbass and Crimea. Western Ukrainian vector ". P. 433 - 440.

Cabinet of Ministers of Ukraine - Order of July 2, 2014 № 677-r. "On the service of the military clergy (chaplaincy) in the Armed Forces, the National Guard, the State Special Transport Service and the State Border Guard Service". URL: https://zakon.rada.gov.ua/laws/show/677-2014-\%D1\%80 ( Accessed 09.09.21).

Chaplain Vyacheslav Bevz: "The soldiers thought we were throwing quotes from the Bible at them, but we just started living with them." URL: http: // www. theinsider.ua/politics/5497bf2b1a684/. (Accessed 09.09.21).

Chaplain and father of 35 children: I want to tell my great-grandchildren how the empire broke its teeth near Mariupol. URL: https: // www. obozrevatel. com/ interview/90348-gennadij-mohnenko-kapellan-mariupol.htm]. (Accessed 09.09.21).

Chaplain Andriy Zelinsky was awarded the Order of the People's Hero of Ukraine. URL: http://glavnoe.ua/ news / n221286]. (Accessed 09.09.21). 
Chaplains of the UGCC in the anti-terrorist operation zone. URL: http://kapelanstvo.org.ua/ category / novyny / kapelany-ugkts-v-zoni-ato / page / 14 /. (Accessed 09.09.21).

Kovtunovich T., Privalko T. (2019) Chaplains. In the service of God and Ukraine. Kyiv, Ukrainian Institute of National Memory. 424 p.

Karpyuk G. (2016) Chaplains are the spiritual fathers of Ukrainian heroes. URL: http://news.ugcc.ua/articles / kapelani_duhovn\% D1\% 96_batki_ukrainskih _geroiv_77964.html. (Accessed 09.09.21).

A monk from Volyn has been at the forefront since the beginning of the antiterrorist operation. URL: https: //www.volyn news.com/ news / vidsichagresoru ukrayin ayedina / monakh-z-volyni-na-peredoviy-z-pochatku-ato /. (Accessed 09.09.21).

Father Lubomyr Yavorsky: During the war in the East, 395 rotations of UGCC priests to the anti-terrorist operation zone have already taken place. URL: http://catholicnews.org.ua/o-lyubomir-yavorskiy-za-chas-viyni-na-shodi-vzhevidbulosya-395-rotaciy-svyashchenikiv-ugkc-u-zoni]. (Accessed 09.09.21).

A chaplain who had been taken prisoner by the Luhansk People's Republic died near Kyiv. URL: https://styler.rbc.ua/ ukr / zhizn / kievom-pogib-kapellan-pobyvavshiyplenu-Inr-1475513871.html. (Accessed 09.09.21).

The program "Soldier returns home" in action. URL: http: // viraichest. com.ua/index.php? option $=$ com_content $\&$ view $=$ article $\&$ id $=9$ : 2011-05-09-1647-16 \& catid $=1$ : bratstvo \& Itemid $=6$. $($ Accessed 09.09.21).

Sudin K. They stand for us... URL: http://old.dyvensvit.org/articles/104871.html. (Accessed 09.09.21).

Tomchuk O. (2017) Pastoral service in the anti-terrorist operation zone among servicemen of the Armed Forces of Ukraine and volunteers. Proceedings of the II All-Ukrainian scientific-practical conference "Ukrainian army: modernity and historical retrospective". Kyiv, Ivan Chernyakhovsky National University of Defense of Ukraine, $160 \mathrm{p}$.

Tomchuk O. (2018) Pastoral care in the volunteer movement: some examples. About dignity. Volunteer movement in Ukraine 2013-2017. Lviv, National Academy of Sciences of Ukraine, Ivan Krypyakevych Institute of Ukrainian Studies, p. 280 - 284.

The first in Ukraine course of military chaplains with the participation of foreign instructors has ended at the National Academy of Land Forces. URL: http: // www. asv.gov.ua /? q = news / 2017/02/10 / u-nacionalny-akademiy-suhoputnbhviysk- -pershyy-v-ukrayini-kurs. (Accessed 09.09.21).

\section{Burakov Y., Tomchuk A. REVIVAL OF CHAPELISM IN THE MODERN UKRAINIAN ARMY}

The article analyzes the phenomenon of formation and development of chaplaincy in the Armed Forces of Ukraine at the present historical stage. It is proved that the Institute of Military Chaplains for the Armed Forces of Ukraine originated from the volunteer pastoral service. Hundreds of priest-volunteers, after the Russian Federation's attack on Ukraine, the annexation of Crimea, and the occupation of Donetsk and Luhansk oblasts, went to eastern Ukraine with prosperity to defend and repel the 
Russian aggressor. The important role of priests-volunteers in the ATO-OOS zone for the development of the volunteer movement of assistance to the Armed Forces of Ukraine is noted. They were among the organizers of trips to the front, collecting humanitarian aid. The Institute of Military Chaplains for the Armed Forces of Ukraine arose from the volunteer pastoral service. This is confirmed by the system of training and practice of pastoral care in the area of anti-terrorist operation environmental protection. The functions of volunteer priests in the ATO-OOS zone in eastern Ukraine included, first of all, confessions, communions, burial of the dead, as well as consecration of equipment, individual conversations with servicemen, and Christian ethics classes. It is stated that the pastoral service is a serious spiritual basis for strengthening the moral and psychological condition of the troops, uniting military teams and successfully completing combat missions. An important point in the organization of pastoral care of the personnel of the Armed Forces of Ukraine in the anti-terrorist operation zone is the creation of a number of public organizations, such as the "Interfaith Battalion of Military Chaplains". The first trips of chaplainsvolunteers from this organization to the anti-terrorist operation zone began in April 2014 and continue to this day. During the existence of the battalion, more than a hundred volunteers of the "Interfaith Battalion of Military Chaplains" visited the anti-terrorist operation zone.

Keywords: chaplain, pastoral service, volunteer-clergyman, volunteer movement of assistance to the Armed Forces of Ukraine. 